\title{
Policing Immigration: A Study of Henning Mankell's Kurt Wallander
}

\author{
Aratrika Mandal \\ IIT Kharagpur, mandalaratrika@iitkgp.ac.in, ORCID id-ooo-ooo3-0465-3642
}

\begin{abstract}
The present paper looks at the representation of inter-national mobility and immigrants in select works from Swedish author Henning Mankell's Kurt Wallander series. Mankell's works are set in Sweden, a country where despite exceptionally inclusive foreign policies lies fault lines within its very social exceptionalism. This challenges the complete denouement that is conventionally observed in the genre of detective fiction. Sweden's geographical proximity with the Baltic countries makes its national boundaries porous, which enables the covert extremist factions to surface and function globally. Illegal human trafficking, followed by the absence of any restriction in compliance with the social welfare state allows one to blend in better, despite the rising anti-immigrant sentiments across the nation in the more recent years. This paper studies the underpinnings of geographical features in the constant run and chase, and how these boundaries are breached by the severity, rigidity, and interdependency of these morally fractured underground networks. Mankell's Faceless Killers (1991) reveals nascent xenophobia provoked by the neoNazi remnants, which is supplemented by local projection of immigrants. These boundaries are further abused in The White Lioness (1993) which has Russian and African fugitives operating deeper networks of extremist groups that manifest an inexistent national security. The paper will reflect on the idea of an immigrant figure as potentially a victim, as a criminal. Finally, an engagement with the physical aspects of the represented urban spaces will facilitate a discussion on the (il)legality of immigration which punctures the welfare state now close to collapse.
\end{abstract}

Keywords: crime fiction, immigration, refugee, world literature, Swedish fiction

"Like the adverts say: Sweden is fantastic," Björk said. "It makes me sick" -Henning Mankell, The Dogs of Riga (1992)

Detective fiction has long been fundamentally concerned with restoring the order after identifying the defect that in all respect counters the rational and moral paradigms of the society (James, 2009). Jakob Stougaard-Nielsen (2020) identifies that the schemes central to the Anglophonic detective fiction tend to "universalize" the genre beyond which the scholarship has only recently moved. Exploring into wider locations, issues of inclusivity, cultural contexts, and social realities has resulted in departure from its orthodoxy to focus more urgent concerns. Adding to this, Karen Saego (2014) insists that crime fiction is equipped to probe why the gamut of a "country's legal, moral and social values" is transgressed. Using this faculty, the paper examines the reactive forces at the ground level in stark contrast with the Swedish welfare state's promises which safeguards immigrants' interests. A close reading of two of Detective Kurt Wallander series by the Swedish crime fiction writer Henning Mankell's Faceless Killers (1991) and

(C) AesthetixMS 2020. This Open Access article is published under a Creative Commons Attribution Non-Commercial 4.o International License (http://creativecommons.org/licenses/by-nc/4.o/), which permits non-commercial re-use, distribution, and reproduction in any medium, provided the original work is properly cited. For citation use the DOI. For commercial re-use, please contact editor@rupkatha.com. 
The White Lioness (1993) will reinforce how the notions of legality of the outsiders are rendered problematic. Finally, it will also discuss the role of urban space and geography in perpetuating crimes and the engagement between city and immigration within the premise of crime fiction.

Sweden forged a fresh narrative of self-gratulatory "Swedish exceptionalism" by altering foreign policies in World War II in order to welcome refugees, asylum seekers, and immigrants from war torn countries to seek a safe residency (Pratt, and McLean, 2015). However, contemporary socio-political tensions in liaison with historical neo-Nazi sentiments have triggered outrage amongst the Swedes, betraying immigrants' position in the society to obscurity. Mankell records this tension in his detective writings between 1991-2009 as Kurt Wallander's testimony of the modern yet crumbling welfare state, purported in incompetent and selfcontradictory politics. Pratt and McLean (2015) identify lawbreakers as an issue that summons no public interest. Wallander enters the cusp where the nature of crime in nascency of change are less motivated by personal intentions rather concealed by acerbic state politics. This marks a prominent shift in the genre as well: unlike Arthur Conan Doyle's and Agatha Christie's whodunnits from the Golden Age of crime fiction or Dashiell Hammett's sordid hardboiled crimes post World War I, Mankell's works underscore the reason why combative legislature is not the final solution to disorder. Wallander's concerns include pertinent issues of stunted manpower that renders the system wholly inefficient. The predecessors and doyens of classic Nordic crime writings, Per Wahlöö and Maj Sjöwall, influence Mankell with their fierce critique of the "fascist tendencies within the police, the betrayal of working class by the purportedly socialist government, [and] the emptiness of the capitalist-bourgeois lifestyle," complying with their leftwing ideology (Holmberg, 2014). Mankell's defense of ethnic rights reflects in his critique of inept social systems, hierarchies, and prejudices that dub themselves as Swedish democracy that fails to safeguard the "most vulnerable members" of the welfare state (Stenport, 2007) amid its own cultural reservations. Unlike his creation Detective Wallander, a conscienteous detective at the Ystad unit whose broken relationships, severe drinking problem and near-diabetic conditions are tantamount to a traumatised body, Mankell is very vocal about the state of affairs in Africa and Palestine.

In Faceless Killers (1991), severity on the socio-cultural and political fronts, flagged by unemployment, and heightened ethnic and racial segregation (Stenport, 2005) are mirrored in brutal murders of the elderly Lövgrens in their house in Lunnarp and the killing of a nameless Somali refugee near Hageholm. The latter is carried out in pure racial spite to avenge the first set of murders. Marie Lövgren's final utterance, "foreign” (Mankell, 1991, 43), leaves Wallander admit if only "she'd said something different" (44), because besides exposing the social narrative laced with xenophobia, it also uncovers the omnipresence of racial supremacy irrespective of socioeconomic locations. The consequences that both Rydberg and Wallander fear (44) are partly manifested in anonymous phone calls threatening them of paying heavy prices for "shielding foreign criminals", (86). It is not to overlook that the Socialist Democratic Party has shared history with neo-Nazi ideology in the formative years (Tomson, 2020). Helene Lööw (1995) extensively covers the key political reasons behind intricate network of subversive racial ideologies. According to her, the kernel of parliamentary anti-immigration parties that populated in 1980 os were sown deep in the anti-immigrant group of 1970 called Bevara Sverige Svenskt (Keep Sweden Swedish, BSS). In 1990, before the Swedish Democratic Party (SD) ran a success, a major bipartisanism broke between the need to harden asylum legislation and complete blockade of refugees' reception after public debate transpired refugees more as a problem and less of a resource (Lööw, 1995, 121). Added to this was new-militant racist group that had emerged the 
preceding year. Their network operated under multiple leaders, which allowed new members to form their own groups-- irrespective of age (125), united by shared objective (122). As a result, a rise of splintered groups peppered the following years as one discreet subculture, considering anyone with contrasting stance an "unenlightened white" (125). Lööw finds this in a leaflet issued by Kreativisten Kyrka in Karlstad, the Swedish chapter of the Church of the Creator formed in 1988 (Kaplan, 2000, 158), which unhesitatedly propagates hate widely-"We show our own people, young as well as old, women as well as men, solidarity and love. But those who are white and betray out people by rave mixing we consider as aliens", (Lööw,156). One of the killers of the Somali refugee, Rune Bergman is a retired police officer, whose close proximity with institution leaves him questioning the ontology of police force. What resonates in Faceless Killers is an onset of crimes associated with these problematic connections: in his social anxiety, he imagines the future when morbid racial offenses will outnumber their undermanned Ystad unit.

Sweden is on the precipice of active cross-national racial extremist groups where the immigration policies stand at loggerheads, and stigmatization, rumor, political prejudices, and anecdotes disfigure the image of the Other. Inclusivity implies more influx of immigrants, asylum seekers, and refugees from the Baltic countries, Africa, and the Middle East subjected to daily acts of discrimination and unmitigated violence. On one hand where there are political-socialeconomical-demographical shifts entailing in surge of immigrants in the mainland (Gold and Nawyn, 2013), there is also a marked inadequacy in the systems, on the other. In the novel, although the Immigration Services are believed to be impermeable, Wallander recalls his colleagues from Malmö disappointed at the "inability of the Immigration Service to handle its job" (Mankell, 1991, p.118). Both Göran Boman and Kurt Wallander agree that "people seeking asylum were dealt with in a chaotic and disorganized manner" (p.123), but that does not justify why the refugee camp in Ystad is just one fencing away from appearing as a concentration campinsinuating this whole arrangement as simply an eyewash. It is only when the camp catches fire does the mismanagement expose itself as the reality for immigrants that is not as comforting as it is made to believe. A lot becomes clear when they pin down the Lövgrens's murderers-two Czech asylum seekers who are political offenders in their home country-which in turn makes the entire assimilation process a very questionable feat. Caveats like this in the official procedures supply to the misrepresentation of the "foreign". Further, the impact of fall of the Eastern bloc and the re-orientation reflect on cross-boundary movement. According to P. Martens (1997), both political and economic foundations of past conceal "the basis for organized crime... (for) strategic geographical positions for smuggling drugs, goods, illegal drugs...” which finally enter Finland and Sweden, equating any movement from across the Baltic with rise in crimes inland. Since inclusivity programs abets influx of immigrants, it also implies more of them get subjected to daily acts of discrimination and unmitigated violence. As obsessive fear leads to xenophobic antagonism, demonizing them as fundamentalists is only convenient means in maintaining the disparity (Pred, 200o). Statistical representations, when gauged with prejudices, vilifies immigrants to taint them more as offenders then ever as the victim.

In Mankell's works, urban space in and outside of Lunnarp and Hageholm becomes an extension of Wallander's mental landscape of his hyphenated acts of recollecting and questioning, resembling Žižek's (2006) eccentric transnational locale that takes readers away from the colonial and ideological centers. Instead of saying that the site could be any place, according to Macleod (2014) Žižek underlines the nuances and conditions of a place such that the reaction to the global forces is localised. Skåne's location on the Baltic coast, its geographical proximity with Denmark and the rest of Europe, the free-visa provision, and the cityscape give a leeway to immigrant 
mobility. In Sweden's case, the eccentric locale is partly infested with racial ghettoism. While Christopher Caldwell (2005) appreciates what Swedish government does in pure social "generosity", he is also sceptical about the demographical report-40 percent of total population in Malmö is of foreign origin, of which over 50 percent unemployed. Moreover, Skåne is infamous for its density of Nazi sympathizers, explaining the locals' vehement opposition to construction of refugee camp in Ystad (Mankell, 1991). The cloisters around Ystad populated by refugees in desperate fashion become the attractive spot for volatility. Therefore, neglect by local authorities play a crucial role in yielding a place's safety (Madanipour, 2010); Wallander recalls of the refugee camp near Lunnarp

... that had been the focus of attacks against foreigners on several occasions. Crosses had been burned at night in the courtyard, rocks had been thrown through windows, buildings had been spray-painted with slogan. The camp, in the old Hageholm, had been established despite vigorous protests from the surrounding communities. And the protest continued. Hostility was flaring up.

The same circumstances behind migration also cause urban spaces to take shapes-even if not entirely amorphous, urban growth depends much on sociological, demographical, and economic make up of the society. However, in the purview of literary elements, city belongs to the minutiae that escaped the notice with changing centres of meaning in the plot (Lutwack, 1984). As David Geherin puts, Lutwack sees place as the "reconstitution in words of those aspects of the actual environment...put together to make up the 'world' ..." which lends characters, events, and themes an existence of their own. He too believes that location embeds into the narrative as more than just the backdrop. Joyce winds life around Dublin, or Kafka's vividness of place in The Castle are some example where geographical space blend into literary space. For Geherin (2008), the process of this transformation is important. However, since crime fiction is essentially born in realism, place becomes indispensable to story-telling. Lucy Andrew and Catherine Phelps (2013) defend that the exercise of mapping the city exposes "the city's secrets" present in the friction that juxtaposition of a respectable public façade with the unpalatable grim and dark underbelly of the city causes. By denouncing to replicate the place, its authenticity is yielded in "reconstructing, remapping, and recreating the city". Crime fiction manifests all the binaries like appearance and reality surface and depth, past and present, truth and falsehood, etc. in the construct of urban space (Scaggs, 2005). In close resemblance, metaphysical implications of crimes unfold in Wallander's mental landscape when he is closer to the road (Nestingen, 2008) -

Wallander gazed thoughtfully at the city as they drove through it... He suddenly felt uneasy. It was as if he expected something to happen any minute. Something he'd better start worrying about right now. Loiuse Akerbom's smiling face flashed across his mind's eye. What had she stumbled upon? He wondered. Had she time to realise she was going to die? (Mankell, 1993)

The White Lioness (1993) is the microcosm of not just Sweden's location in the world of international crimes, but also of world politics. As Stougard-Nielsen points, Mankell uses diverse geographical nodes and settings to explore "changing and competing notions of race, justice and sociopolitical change" (2020, p.82). Although the major part is primarily set in South Africa where a pro-apartheid faction plots to assassinate Nelson Mandela, the relationship between civic life and space incentivises Sweden as the ideal training ground for Mabasha. A former KGB agent, Konovalenko sternly asserts that they cannot afford to be seen, recorded, or be known of in the 
foreign country. This resonates with what Eric Sandberg (2020) conceptualises of city-it is a pool of signifiers for danger that also houses a relatively safe space. By extension, a house, a car, or any form of enclosure can be this "place of safety", which for them is an old deserted barn. Nothing beyond erasing the evidence of being seen motivates Konovalenko to kill Louise Akerblom, who was in the same area looking for a specific house. Ten chapters later, readers discover him explain Mabasha the urgency of removing any evidence of being seen, "we don't exist. We'll be disappearing from here in few days, and everthing must be as if we had never been here" (Mankell, 1993, p.169). Socio-topographical elements like well and pond are used to dispose her body and car respectively. Ironically, Skåne, in Louise's own words, was "a lovely place" (p.5) and "yet secretive (because) what seemed at first sight to be so flat could be unexpectedly change and reveal deep hollows like isolated islands with houses and farms" (p.6). David Schmid uses the metropolis of Doyle's A Study in Scarlett (1887) to view city as the "source of both fear and attraction, danger and enchantment...",. He connects danger with the size and anonymity of the city that provides for the hiding places for the criminals, while fascination with "the epitome of whimsical and bizarre" that rescues Holmes from his "bouts of ennui". Holmes's habit of taking long walks eventually takes the reader to the "dark and forbidden areas" that conflict with "Doyle's predominantly middle-class readership" (Schmid, 1995). When Louise conjectures from the Mercedes and BMW parked near the farmhouse, that the inhabitants were "not short of cash" (p.7), as Nestingen (2008) asserts, Mankell becomes considerate "of relationships that underpin socioeconomic and cultural difference in times of globalization, while urging stronger alliances for responding to socioeconomic gaps and cultural misconception", and the White Lioness tethers on this difference.

The fact that discotheque called 'Aurora' in Soder is frequented mostly by "the Black clientele" in the locality demonstrates the correlation between demographical concentration and urban joints. Places forge identity based on its inhabitants, and The White Lioness asserts that through both Sweden and South Africa. Kleyn's own home in Bezuidenhout Park, Johannesburg, is a sanctum constituted by his wife Miranda and daughter Matilda-both of whom are compatriots to the Black liberation movement. Isolated and guarded from the periphery, this house has once shielded Miranda under the pretence of an Englishman's servant. Yet, its sanctity is marred by differences in racial identities appended in Apartheid politics that undercuts his own political propaganda. Matilda's alliance with the ANC debunks the arrangement that proliferates under Kleyn's supervision, except for it brings Georg Scheeper to Kliptown's detached shanty, close to the "another world", whose viscerality makes him realise of spaces that is separated and cannot be conquered (Mankell, 1993, pp.427-29). Blindfolding Scheepers symbolises censuring of the Black reality pinned by Apartheid. Tore Bjørgo (1993) notes that "social setting, where the group dynamic processes" play a distinct role in executing the act of violence, which in this case is the white Afrikaners against abolition of apartheid. Here, the assaulting parties are borderline terrorist groups. They are founded on racist and sectarian ideologues with target groups belonging to minorities, which in this case are immigrants and Blacks.

In conclusion, the paper has tried to touch upon those issues that obfuscate both immigration and identities. Over the period of serving the KGB, Konovalenko has "built up a reserve of foreign currency", and has manufactured identities "in the form of passports and other documents", switching into which facilitates illegal trade across national borders. This rarefied version of misrepresented identities could be seen in the Swedish suburb Tensta, which despite its immigrants density, is reported as a "vulnerable area" by both media and the police (Ritz, 2016). Here, not only are the people but also is the location fringed away, ousted, because this cloister is 
the only safe space their migrant status can acquire. Repercussion of (mis) projection deflects the interests of inclusivity and globalization. In both these works, distancing from the racial and ethnic other is administered in violence. In an interview with The Scotsman, Mankell asserts that it is only fair "to be honest about involvement of foreigners in Swedish crime..; turning a politically- correct blind eye to the problem will only ultimately exacerbate racism" (2010). The nature of crime changed because society did gradually, and crimes are an efficient way to talk about contradictions in society" (O'Yeah, 2009). If the likes of the Czech criminals in Faceless Killers is what Wallander anticipates for future, the Nazi sympathizers and proto-anarchical tendencies should trigger the fault lines. On one hand where the Somali asylum seeker and Iranian refugee are witch hunted by populist right ideologues for being outsiders, both Mabasha and Konovalenko in The White Lioness are drawn to the projection of the "other" that Bergman's and Kleyn's unjustifiable ethnic fanaticism have manufactured. Wallander ruminates the Somali's murder as "a new kind of murder" by acknowledging that the underlying reasons are becoming more vicious which lodges the concept of legal and illegal seek a fresh view. Representation on media and official data provides only a story that complies with the status quo, and the two novels have shown how identity becomes a variable in promoting crime. The reluctance of the authority and bureaucracy further underscores the notoriety that racial hegemony imparts. Thus, the detective does not leave at welding a resolution, he questions for a more robust mechanism that could keep the inevitable shift of globally changing world of fluidic identities safe.

\section{References}

Bjørgo, T. (1993). Militant neo-Nazism in Sweden. Terrorism and Political Violence, 5(3), 28-57.

Caldwell, C. (2005). The Swedish Dilemma. Retrieved from Washington Examiner.

Geherin, D. (2008). Scene of the Crime: the Importance of place in crime and mystery fiction. North Carolina: McFarland \& Company.

Gold, S. J. \& Nawyn S. J. (2013). Introduction. In S. J. Steven J. Gold (Ed.), The Routledge International Handbook of Migration Studies (pp. 1-8). London: Taylor\&Francis.

Holmberg, J.H. (Ed.). (2014). A Darker shade of Sweden. New York: Grove Atlantic.

Interview: Henning Mankell, author. (2010, February 02). The Scotsman. Retrieved October 172020. https://www.scotsman.com/arts-and-culture/interview-henning-mankell-author-1734222

James, P.D. (2009). Talking About Detective Fiction. New York: Alfred A. Knopf.

Kaplan, J. (2000). Encyclopedia of White Power: A Sourcebook on the Radical Racist Right. Maryland: AltaMira Press.

Lutwack, Leonard. (1984). The Role of Place in Literature. New York: Syracuse University Press.

Lööw, H. (2007). Racist violence and criminal behaviour in Sweden: Myths and Reality. Terrorism and Political Violence, 7(1), 119-161.

Macleod, A. (2014). The contemporary fictional police detective as critical security analyst: insecurity and immigration in the novels of Henning Mankell and Andrea Camilleri. Secutiy Dialogue, 45(6), 515529.

Madanipour, A. (2010). Marginal public spaces in European cities. In Whose Public Space International Case Studies in Urban Studies in Urban Design and Development. New York: Taylor \& Francis. (pp.111-130)

Mankell, H. (1991). Faceless Killers (2009 ed.). (S. T. Murray, Trans.) London: Random House.

Mankell, H. (1992). The Dogs of Riga (2009 ed.). (L. Thompson, Trans.) London: Random House.

Mankell, H. (1993). The White Lioness (2009 ed.). (L. Thompson, Trans.) London: Random House.

Martens, P. L. (1997). Immigrants, crime, and Criminal Justice in Sweden". Crime and Justice, 21, 183-255. 
Nestingen, A. K. (2008.). The Burned out Policeman: Henning Mankell's Transnational Police Procedural. In Crime and Fantasy in Scandinavia: Fiction, Film and Social Change.223-254.

O’Yeah, Z. (2009). Interview with Henning Mankell, "Crime fiction is the mirror". Retrieved October 16, 2020. http://www.zacoyeah.com/interview-with-henning-mankell-crime-fiction-is-the-mirror

Pratt, J and McLean, T. (2015) Inspector Wallander's angst, social change and the reconfiguration of Swedish Exceptionalism Punishment \& Society, 17(3) 322-344.

Pred, A. (2000). Even in Sweden: Racisms, Racialized Spaces, and the Popular Geographical Imagination. London: UC Press.

Ritz, J-D. (2016, November 03) People in Sweden's Alleged 'No-Go Zones' Talk About What It's Like to Live There. Vice. https://www.vice.com/sv/article/ava85k/people-of-the-no-go-zones-talk-about-whatits-like-to-live-in-no-go-zones-726.

Sandberg, E. (2020). City. In J. G. Janice Allan (Ed.), Routledge Companion to Crime Fiction. London: Taylor and Francis. 335-342.

Scaggs, J. (2005) Crime Fiction: The New Critical Idiom. London: Taylor and Francis.

Seago, K. (2014). Introduction and overview: crime (fiction) in translation. The Journal of Specialised Translation(22), 2-14.

Schmid, D. (1995) Imagining Safe Urban Space: the Contribution of Detective Fiction to Radical Geography. Antipode, 27(3), 242-269.

Stenport, A. W. (2007). Bodies Under Assault: Nation and Immigration in Henning Mankell's "Faceless Killers". Scandinavian Studies, 79(1), 1-24.

Stougaard-Nielsen, J. (2020). World Literature. In J. G. Janice Allan (Ed.), Routledge Companion to Crime Fiction. London: Taylor and Francis. 76-84.

Tomson, D. L. (2020). The Rise of Sweden Democrats: Islam, Populism and the End of Swedish Exceptionalism. Retrieved from Brookings.

Žižek, S. (2003, October). Parallax. Retrieved from London Review of Books. https://www.lrb.co.uk/thepaper/v25/n22/slavoj-zizek/parallax

Aratrika Mandal is a Research Scholar at the Department of Humanities and Social Sciences in IIT Kharagpur. She is studying Nordic noir. 